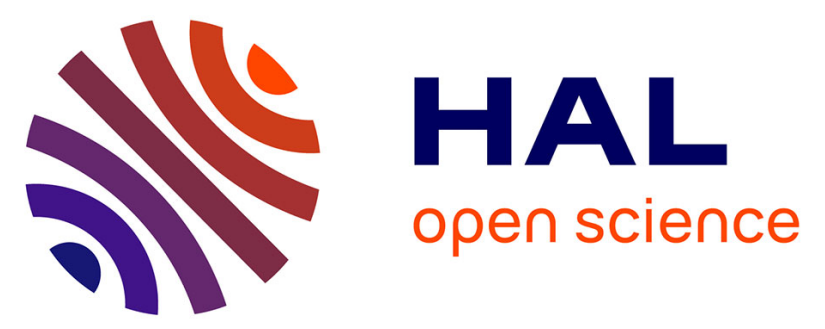

\title{
Synthesis of ATP derivatives of compounds of the mevalonate pathway (isopentenyl di- and triphosphate; geranyl di- and triphosphate, farnesyl di- and triphosphate, and dimethylallyl diphosphate) catalyzed by T4 RNA ligase, T4 DNA ligase and other ligases. Potential relationship with the effect of bisphosphonates on osteoclasts
}

\author{
Maria A. Günther Sillero, Anabel de Diego, Janeth E.F. Tavares, Joana A.D.
} Catanho Da Silva, Francisco J. Pérez-Zúñiga, Antonio Sillero

\section{To cite this version:}

Maria A. Günther Sillero, Anabel de Diego, Janeth E.F. Tavares, Joana A.D. Catanho Da Silva, Francisco J. Pérez-Zúñiga, et al.. Synthesis of ATP derivatives of compounds of the mevalonate pathway (isopentenyl di- and triphosphate; geranyl di- and triphosphate, farnesyl di- and triphosphate, and dimethylallyl diphosphate) catalyzed by T4 RNA ligase, T4 DNA ligase and other ligases. Potential relationship with the effect of bisphosphonates on osteoclasts. Biochemical Pharmacology, 2009, 78 (4), pp.335. 10.1016/j.bcp.2009.04.028 . hal-00493523

\section{HAL Id: hal-00493523 \\ https://hal.science/hal-00493523}

Submitted on 19 Jun 2010

HAL is a multi-disciplinary open access archive for the deposit and dissemination of scientific research documents, whether they are published or not. The documents may come from teaching and research institutions in France or abroad, or from public or private research centers.
L'archive ouverte pluridisciplinaire HAL, est destinée au dépôt et à la diffusion de documents scientifiques de niveau recherche, publiés ou non, émanant des établissements d'enseignement et de recherche français ou étrangers, des laboratoires publics ou privés. 


\section{Accepted Manuscript}

Title: Synthesis of ATP derivatives of compounds of the mevalonate pathway (isopentenyl di- and triphosphate; geranyl di- and triphosphate, farnesyl di- and triphosphate, and dimethylallyl diphosphate) catalyzed by T4 RNA ligase, T4 DNA ligase and other ligases. Potential relationship with

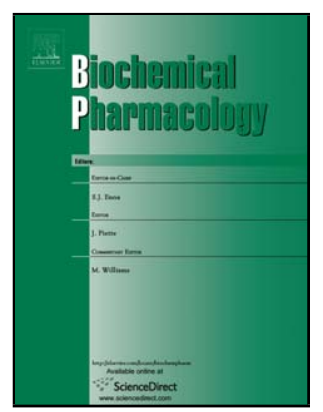
the effect of bisphosphonates on osteoclasts

Authors: Maria A. Günther Sillero, Anabel de Diego, Janeth E.F. Tavares, Joana A.D. Catanho da Silva, Francisco J. Pérez-Zúñiga, Antonio Sillero

PII: S0006-2952(09)00265-2

DOI: doi:10.1016/j.bcp.2009.04.028

Reference: BCP 10143

To appear in: $\quad B C P$

Received date: 25-2-2009

Revised date: $\quad 31-3-2009$

Accepted date: $\quad$ 6-4-2009

Please cite this article as: Sillero MAG, de Diego A, Tavares JEF, Silva JADC, PérezZúñiga FJ, Sillero A, Synthesis of ATP derivatives of compounds of the mevalonate pathway (isopentenyl di- and triphosphate; geranyl di- and triphosphate, farnesyl diand triphosphate, and dimethylallyl diphosphate) catalyzed by T4 RNA ligase, T4 DNA ligase and other ligases. Potential relationship with the effect of bisphosphonates on osteoclasts, Biochemical Pharmacology (2008), doi:10.1016/j.bcp.2009.04.028

This is a PDF file of an unedited manuscript that has been accepted for publication. As a service to our customers we are providing this early version of the manuscript. The manuscript will undergo copyediting, typesetting, and review of the resulting proof before it is published in its final form. Please note that during the production process errors may be discovered which could affect the content, and all legal disclaimers that apply to the journal pertain. 


\section{Synthesis of ATP derivatives of compounds of the mevalonate}

pathway (isopentenyl di- and triphosphate; geranyl di- and

triphosphate, farnesyl di- and triphosphate, and dimethylallyl

diphosphate) catalyzed by T4 RNA ligase, T4 DNA ligase and other

ligases. Potential relationship with the effect of bisphosphonates on osteoclasts.

Maria A. Günther Sillero, Anabel de Diego, Janeth E. F. Tavares, Joana A.

D. Catanho da Silva, Francisco J. Pérez-Zúñiga and Antonio Sillero*

Departamento de Bioquímica, Instituto de Investigaciones Biomédicas Alberto Sols, UAM/CSIC, Facultad de Medicina, 28029 Madrid, Spain.

Abbreviations: $A p_{4} A$, diadenosine $5^{\prime}, 5^{\prime \prime}-P^{1}, P^{4}$-tetraphospate; Apppl or isopppA, ATP derivative of iso-PP; BP, a bisphosphonate; dim-PP, dimethylallyl diphosphate; dim-pppA, ATP derivative of dim-PP; far-PP or far-PPP, farnesyl di- or triphosphate; ger-PP or ger-PPP, geranyl di- or triphosphate; iso-PP or iso-PPP, isopentenyl di- or triphosphate; iso-pppA or iso-ppppA, ATP derivative of iso-PP or iso-PPP; mev-PP or mev-PPP, compounds of the mevalonate pathway containing two or three terminal phosphates; mev-pppA or mev-ppppA, ATP derivatives of mev-PP or mev$\mathrm{PPP}$; N-BP, a bisphosphonate containing nitrogen; non-N-BP, a bisphosphonate not containing nitrogen; $\mathrm{p}_{4} \mathrm{~A}$, adenosine $5^{\prime}$-tetraphosphate.

*Corresponding Author:

Fax: +34915854401

E-mail: antonio.sillero@uam.es (A.S.) 


\section{ABSTRACT}

Compounds of the mevalonate pathway containing a terminal di- or triphosphate (mev-PP or mev-PPP) were tested as substrates of several enzyme ligases (T4 RNA ligase, T4 DNA ligase, firefly luciferase and other ligases) for the synthesis of ATP derivatives of the mev-pppA or mev-ppppA type. T4 RNA ligase, in the presence of ATP and the substrates: geranyl, farnesyl or isopentenyl triphosphates, and geranyl, farnesyl, dimethylallyl or isopentenyl diphosphates, all at $0.3 \mathrm{mM}$ concentration, catalyzed the synthesis of the corresponding ATP derivatives at a relative rate of activity of: $7.6 \pm 1.4 \mathrm{mU} / \mathrm{mg}$ or $100 \% ; 39 \% ; 42 \% ; 24 \% ; 18 \% ; 12 \%$ and $6 \%$, respectively. Inhibition (\%) of the synthesis by excess of substrate $(0.8 \mathrm{mM}$ vs. $0.3 \mathrm{mM}$ ) was observed with farnesyl diphosphate (99\%); farnesyl triphosphate (96\%) and geranyl triphosphate (32\%). $V_{\max }, K_{\mathrm{m}}, K_{\text {cat }}$ and $K_{\text {cat }} / K_{\mathrm{m}}$ values were also determined. The $K_{\text {cat }} / K_{\mathrm{m}}$ values calculated were for: farnesyl triphosphate, 166; geranyl triphosphate, 52.2; farnesyl diphosphate, 12.1; geranyl diphosphate, 8.6; isopentenyl triphosphate, 6.7; dimethylallyl diphosphate, 3.1 and isopentenyl diphosphate, 0.9. Similar results were obtained with T4 DNA ligase. The above-mentioned compounds were also substrates of firefly luciferase synthesizing the mevpppA or mev-ppppA derivatives. In our hands, neither the acyl- or acetylCoA synthetases nor the ubiquiting activating enzyme (E1) catalyzed the synthesis of ATP derivatives of these compounds. The results here presented could be related with the mechanism of action of bisphosphonates on osteoclasts or tumor cells. 


\section{Introduction}

Bisphosphonates (P-C(R1)(R2)-P) (BPs) are widely used in the treatment of osteoporosis and other bone diseases [1]. After being fixed to bone tissues [2-4], they exert a damaging effect on osteoclasts through two classically described mechanisms: a) as substrates of different ligases generating BP derivatives of ATP through reactions 1,$5 ; 1 \mathrm{a}, 5 \mathrm{a}$ (see Table 1); this effect is supposed to be carried out by the first generation, or not containing nitrogen, bisphosphonates (non-N-BPs) [5-9]; b) as inhibitors of the mevalonate pathway (Fig. 1) by causing several pathological consequences such as: inhibition of the synthesis of cholesterol and its derivatives and, secondarily, inhibition of the post-translational modifications (isoprenylation, farnesylation) of important regulatory proteins [10-15].

The stimulation of the synthesis of Apppl (here named iso-pppA, see nomenclature below) in osteoclasts and J774 macrophages when treated with nitrogen containing bisphosphonates (N-BPs) (zoledronate, risedronate, ibandronate, alendronate) has been recently reported [16]. Apppl is the compound resulting from the union of the AMP moiety of ATP with isopentenyl pyrophosphate, a component of the mevalonate pathway. The synthesis of iso-pppA correlated well with the capacity of those BPs to inhibit the mevalonate pathway. Moreover, iso-pppA, as well as the ATP derivative of clodronate $\left(A p p C C{ }_{2} p\right)$, inhibited the mitochondrial ADP/ATP translocase and caused apoptosis in osteoclasts [16, 17]. Apppl (iso-pppA) can then be an interesting compound to be considered in the mechanism of action of bisphosphonates. Mönkkönen et al. [16] suggested that the 
synthesis of iso-pppA could be catalyzed by aminoacyl tRNA synthetases through reactions 1 and 6 (Table 1).

The work here presented started by exploring the synthesis of iso-pppA by different enzyme ligases, and has been further extended to explore the synthesis of similar derivatives $\left(m e v-p_{n} A\right)$ of other compounds of the mevalonate pathway, based on the following grounds.

A. In our experience with enzyme ligases [18], the formation of the complex E-X-AMP (or E-AMP) is rather specific for each enzyme (Table 1, reactions 1 or 1a). Once the E-X-AMP (or E-AMP) complex is formed, its AMP moiety reacts forming a phosphodiester bond with nucleotides containing 2,3 , or more terminal phosphates or even with polyphosphate chains of variable length (Table 1, reactions 2, 3 and 4). However, each ligase behaves differently concerning the synthesis of $A(p)_{n} N$ or $(p)_{n} A[18]$; as an example, the synthesis of compounds as bizarre as $p_{20} A$ or $A p_{16} A$ are catalyzed by luciferase in the presence of luciferin, ATP and a polyphosphate chain [19]. B. Several ligases catalyze the transfer of AMP from the E-X-AMP or EAMP complexes to a bisphosphonate, with formation of the corresponding derivative (reactions 5, 5a, Table 1) [8, 9].

C. The interesting finding of the occurrence of Apppl (iso-pppA) in osteoclasts incubated with zoledronate [16] prompted us to investigate the possible synthesis by ligases of compounds of the mev-pppA type (where

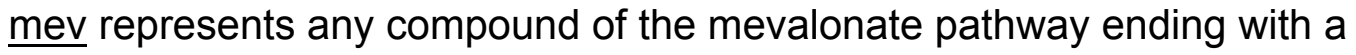
terminal pyrophosphate, (Fig. 1)). As shown here, this synthesis can be catalyzed by a variety of AMP forming ligases. This finding, apart from being of potential basic interest, may help to unravel the mechanisms of 
action of bisphosphonates, or even may have metabolic or therapeutic implications.

\section{Materials and methods}

\section{1. Materials}

Mevalonate pathway compounds: $\gamma, \gamma$, dimethylallyl pyrophosphate, Cat.

No. D4287; farnesyl pyrophosphate, Cat. No. F6892; farnesyl triphosphate, Cat. No. F1928; geranyl pyrophosphate, Cat. No. G6772; geranyl triphosphate, Cat. No. G2418; isopentenyl pyrophosphate, Cat. No. I0503, and isopentenyl triphosphate, Cat. No. I1282, were from Sigma.

Enzyme ligases: T4 RNA ligase (EC 6.5.1.3) was from BioLabs (M0204S, lots 40 and 0410802), with a specific activity of 12,000 U/mg [8]. T4 DNA ligase (EC 6.5.1.1) from E. coli, was from Roche (Cat No. 10716359001 , lot 12407122 ) with a specific activity of $3,000 \mathrm{U} / \mathrm{mg}$ [9]; acylCoA synthetase (EC 6.2.1.3), Ref. A-3352 (lot 115K11611); acetyl-CoA synthetase (EC 6.2.1.1), Ref. A-1765 (lot 045K1431); Ub activating enzyme (E1) Ref. U1758 (lot 027K1384) and luciferase (EC 1.13.12.7), Ref. L-9506 (lot 66H8275) were from Sigma.

Other enzymes: Yeast inorganic pyrophosphatase (EC 3.6.1.1) was from BioLabs (Cat. No. 2403); shrimp alkaline phosphatase (EC 3.1.3.1) was from Roche (Ref. 1758250); phosphodiesterase I from crotalus durissus was from Boehringer Mannheim, Germany (now Roche).

Other materials: Sodium tripolyphosphate $\left(\mathrm{P}_{3}\right)$ was from Sigma (Ref. T5633). [ $\left.{ }^{32} \mathrm{P}\right]$ ATP $3000 \mathrm{Ci} / \mathrm{mmol}$ ) was from Perkin Elmer. TLC silica-gel fluorescent plates were from Merck. Radioactively labelled nucleotides 
were quantified with the help of a Typhoon Trio from GE Healthcare. HPLC was carried out in a Hewlett Packard chromatograph (model 1090) with a diode array detector. The Hypersil ODS column (4.6 x $100 \mathrm{~mm})$ was from Hewlett Packard.

\subsection{Synthesis of ATP derivatives of compounds of the mevalonate pathway catalyzed by ligases}

T4 RNA ligase. The reaction mixtures $(0.02 \mathrm{ml})$ contained $50 \mathrm{mM}$ Tris/HCl (pH 7.4), $1 \mathrm{mM}$ dithiothreitol (DTT), $5 \mathrm{mM} \mathrm{MgCl}_{2}, 0.1 \mathrm{U}$ of pyrophosphatase, $0.02 \mathrm{mM}\left[\alpha^{32} \mathrm{P}\right] \mathrm{ATP}(0.4 \mu \mathrm{Ci}), 1 \mathrm{mM}$ phosphoenolpyruvate, $0.2 \mathrm{U}$ pyruvate kinase, compounds of the mevalonate pathway and enzyme as indicated. After incubation at $30^{\circ} \mathrm{C}$ the reaction mixtures were analysed by thin-layer chromatography (TLC) or high-pressure liquid chromatography (HPLC) [8].

T4 DNA ligase. The reaction mixtures $(0.02 \mathrm{ml})$ contained $50 \mathrm{mM}$ Hepes/KOH (pH 7.2), $1 \mathrm{mM}$ DTT, $5 \mathrm{mM} \mathrm{MgCl}_{2}, 0.1 \mathrm{U}$ of pyrophosphatase, $0.02 \mathrm{mM}\left[\mathrm{a}-{ }^{32} \mathrm{P}\right] \mathrm{ATP}(0.4 \mu \mathrm{Ci})$, compounds of the mevalonate pathway and enzyme as indicated. After incubation at $30^{\circ} \mathrm{C}$ the reaction mixtures were analysed by TLC [9].

Luciferase. The reaction mixtures $(0.02 \mathrm{ml})$ contained $50 \mathrm{mM}$ Hepes/KOH (pH 7.5), $5 \mathrm{mM} \mathrm{MgCl} 2,0.1 \mathrm{U}$ of pyrophosphatase, $0.02 \mathrm{mM}[\alpha-$ $\left.{ }^{32} \mathrm{P}\right] \mathrm{ATP}(0.4 \mu \mathrm{Ci}), 0.02 \mathrm{mM}$ D-luciferin, compounds of the mevalonate pathway and enzyme as indicated. The enzyme was diluted in $0.5 \mathrm{M}$ 
Hepes/KOH $(\mathrm{pH} 7.5) / 10 \%$ glycerol $/ 1 \mathrm{mM}$ DTT. After incubation at $30^{\circ} \mathrm{C}$ the reaction mixtures were analysed by TLC.

Other enzymes. acyl-CoA synthetase [20], acetyl-CoA synthetase [21] and the ubiquitin activating enzyme (E1) [22] were assayed as previously described.

Enzyme units $(U)$. One unit $(U)$ is the amount of enzyme transforming one $\mu \mathrm{mol}$ of substrate per min.

Analysis by TLC. Aliquots of $1.5 \mu$ of the reaction mixtures were spotted on silica gel plates and developed for $2 \mathrm{~h}$ in dioxane:ammonium hydroxide:water ( $6: 1: 6$ by volume).

\subsection{Nomenclature.}

The compounds here synthesized are structurally related to dinucleoside polyphosphates $\left(\mathrm{Np}_{n} \mathrm{~N}^{\prime}\right)$ or nucleoside(5')oligophospho(5')nucleoside or $N\left(5^{\prime}\right) p_{n}\left(5^{\prime}\right) N^{\prime}$. There are a plethora of such compounds, some of them of physiological relevance [23-25]. Most of their abbreviations start and end with a capital letter representing a nitrogenous base, for instance $A p_{4} A$ or AppppA or diadenosine tetraphosphate. For a review on the chemistry and nomenclature of dinucleoside polyphosphates see [26].

The recently discovered ATP derivative of isopentenyl diphosphate has been abbreviated as Apppl (I standing for isopentenyl) and named as 1adenosin-5'-yl ester 3-(3-methylbut-3-enyl) ester [16]. In this report, to avoid confusion with the already well-established nomenclature for the dinucleoside polyphosphates, the ATP derivatives of the compounds of the mevalonate pathway have been abbreviated using the first three letters of 
its name, with a dash followed by the number of inner phosphates and the suffix adenosine. So, the ATP derivatives of isopentenyl diphosphate or of farnesyl triphosphate have been abbreviated as iso-pppA or far-ppppA, respectively. In general, the compounds of the mevalonate pathway covalently bound to AMP are named as mev-(p)nA. (Table 1).

\section{Results}

\subsection{Synthesis and characterization of isopentenyl triphospho adenosine} (iso-pppA) by T4 RNA ligase. Analysis by TLC.

To investigate whether the ligases capable to synthesize bisphosphonate derivatives of ATP, as already shown in our laboratory $[8,9]$, were able to synthesize as well, the ATP derivative of isopentenyl pyrophosphate (Apppl [16], here iso-pppA), the enzyme T4 RNA ligase was firstly tested. The reaction mixture contained of $0.02 \mathrm{mM}\left[\alpha-{ }^{32} \mathrm{P}\right] \mathrm{ATP}$ and $1 \mathrm{mM}$ iso-PP.(Fig. 2, lanes 3,5,and 7). At different times of incubation samples were taken and analyzed by TLC as described in Materials and methods. Two control reactions (with no added enzyme (Fig. 2, lane 1) and with no added iso-PP

(Fig. 2, lanes 2, 4 and 6), were run in parallel. In the reaction mixture containing iso-PP (Fig. 2, lanes 3, 5 and 7) a new radioactive spot migrating ahead of AMP and increasing with incubation time was formed. This spot, the presumptive iso-pppA derivative, was not degraded by alkaline phosphatase (lane 9) and, after inactivation of the phosphatase, treatment with snake venom phosphodiesterase (SVP) rendered labeled AMP. In our 
view, these results indicate that the synthesis of iso-pppA catalyzed by T4 RNA ligase takes place through reactions $1 \mathrm{a}$ and $6 a$ (Table 1).

In the control reactions (lanes 2, 4 and 6), containing T4 RNA ligase but not iso-PP, the formation of radioactive spots that increased with incubation time and co-migrated with standards of $A M P$ and $A p_{4} A$, were also observed. Treatment with alkaline phosphatase, resulted in the appearance of a new spot (that eluted slightly above a standard of ADP) and was resistant to phosphodiesterase. This product, unrelated to the presence or absence of isopentenyl-PP, could not be identified.

\subsection{Synthesis and characterization of isopentenyl tetraphospho adenosine (iso-ppppA) by T4 RNA ligase. Analysis by HPLC}

Reaction mixtures $(0.08 \mathrm{ml})$ containing $60 \mathrm{U}$ T4 RNA ligase, $0.3 \mathrm{mM}$ ATP and $0.4 \mathrm{mM}$ Iso-PPP (other components as indicated in Material and methods), were incubated for 6 and $20 \mathrm{~h}$, and aliquots analyzed by HPLC

(Fig. 3, b and c). The rest of the reaction mixture was treated with $1 \mu \mathrm{l}(1 \mathrm{U})$ of shrimp alkaline phosphatase (AP) (for $2 \mathrm{~h}$ at $\left.37^{\circ} \mathrm{C}\right)($ Fig. $3, \mathrm{~d}$ ) and, after inactivation of the phosphatase by heating, treated with snake venom phosphodiesterase (SVP) (Fig. 3, e). The control reaction with no added enzyme is shown in (Fig. 3, a). As shown here, the presumptive iso-ppppA, (with a retention time $\left(t_{R}\right)$ of around $54 \mathrm{~min}$ ), was resistant to the phosphatase and yielded AMP when incubated with phosphodiesterase (Fig. 3, e). In the course of the reaction, the synthesis of a compound $\left(t_{R}\right.$ of $34 \mathrm{~min}$ ) that co-migrated with a standard of $\mathrm{Ap}_{4} \mathrm{~A}$ (not shown) was also observed (Figs. 3, b, c and d). 


\subsection{A comparative study of several compounds of the mevalonate pathway} as substrates of T4 RNA ligase

On the accounts presented in the Introduction, the following compounds of the mevalonate pathway were assayed comparatively as substrates of T4 RNA ligase, at two different concentrations ( 0.3 and $0.8 \mathrm{mM})$ : isopentenyl triphosphate (iso-PPP); isopentenyl diphosphate (iso-PP); farnesyl triphosphate (far-PPP); farnesyl diphosphate (far-PP); geranyl triphosphate (ger-PPP); geranyl diphosphate (ger-PP) and dimethylallyl diphosphate (dim-PP). As shown in Fig.4, new radioactive spots corresponding to the ATP derivatives of the above substrates were clearly observed. The initial velocity values, expressed as $\mathrm{mU} / \mathrm{mg}$ of protein (mean of 2-4 determinations) were calculated and represented in Fig. 5. The relative activities (\%) (calculated at the $0.3 \mathrm{mM}$ concentration) to synthesize the corresponding mev- $p_{n} A$ derivatives of the following substrates were: gerPPP, $100 \%$ or $7.6 \mathrm{mU} / \mathrm{mg}$; iso-PPP, $42 \%$; far-PPP, 39\%; ger-PP, 24\%; farPP, $18 \%$; dim-PP, $12 \%$ and iso-PP, $6 \%$. Inhibition by excess of substrate was observed with far-PP, far-PPP and ger-PPP; the enzyme activities determined with these substrates at $0.8 \mathrm{mM}$ were $<1 \%, 7 \%$ and $68 \%$, respectively, of those obtained at $0.3 \mathrm{mM}$ (Figs. 4 and 5). The inhibition was also followed at different concentrations of substrate (far-PP and far-PPP) as shown in Fig. 6a,b, and Fig.6c,d, respectively.

The $V_{\text {max }}, K_{m}, K_{\text {cat }}$ and $K_{\text {cat }} / K_{m}$ values of T4 RNA ligase determined for each one the substrates tested are compiled in Table 2 . The $V_{\max }$ values were higher for the substrates with a terminal triphosphate. Regarding $K_{m}$ values, iso-PP and iso-PPP were the substrates with the lowest affinity for the 
enzyme $\left(K_{\mathrm{m}}\right.$ values around $\left.4 \mathrm{mM}\right)$, while the higher efficacy $\left(K_{\mathrm{cat}} / K_{\mathrm{m}}\right)$ was found for far-PPP, a compound whose derivative formation is inhibited by an excess of substrate (see Figs. 4, 5 and 6c, d).

\subsection{Synthesis of ATP derivatives of compounds of the mevalonate pathway catalyzed by T4 DNA ligase}

This point started with the synthesis and characterization of iso-pppA using iso-PP as substrate. The reaction mixtures contained $0.02 \mathrm{mM}\left[\alpha-{ }^{32} \mathrm{P}\right] \mathrm{ATP}$, $1 \mathrm{mM}$ iso-PP, and other components as indicated in Material and methods (Fig. 7). Samples were taken from the reaction mixture at different times of incubation and analyzed by TLC. As performed with T4 RNA ligase (Fig. 2), two control reactions (with no added enzyme (Fig. 7, lane 1) and with no added iso-PP (Fig. 7, lanes 2, 4 and 6), were run in parallel. In the reaction mixture containing iso-PP (Fig. 7, lanes 3, 5 and 7) a new spot migrating ahead of AMP and increasing with incubation time was formed. This spot (presumptive iso-pppA), as with T4 RNA ligase (Fig. 2), was not degraded by alkaline phosphatase (AP) (lane 9), and treatment with snake venom phosphodiesterase (SVP) rendered AMP, demonstrating the synthesis of iso-pppA from ATP and iso-PP. As occurred with T4 RNA ligase (Fig. 2), the control reactions with added enzyme but not iso-PP (Fig. 7, lanes 2, 4 and 6), showed also spots that co-migrated with standards of AMP and $A p_{4} A$. After alkaline phosphatase treatment, a spot resistant to phosphodiesterase, eluting slightly above a standard of ADP, was also observed.

Before comparing the results obtained with T4 RNA ligase (Fig. 2) and T4 DNA ligase (Fig. 7), it should be remind that the T4 RNA ligase assays 
include an ATP regenerating system, due to the ATPase activity present in the commercial preparation of T4 RNA ligase [8]. Therefore, ADP (an usual contaminant of the $\left[\alpha-{ }^{32} \mathrm{P}\right]$ ATP preparation) is not observed, while it is clearly appreciated in the T4 DNA ligase assays that do not include the ATP regenerating system. Since both enzymes are able to catalyze the synthesis of $A p_{4} A$ from ATP $[27,28]$, a small amount of $A p_{4} A$ used to be formed in the absence or presence of iso-PP. However, in the context of this work the important points are: i) the appearance of a product, present exclusively in the reaction mixtures containing iso-PP; ii) its resistant to alkaline phosphatase and iii) the formation of AMP following treatment with phosphodiesterase.

All the compounds tested as substrates of T4 RNA ligase (see above) were also assayed as substrates of T4 DNA ligase, at a concentration of 0.3 and $0.8 \mathrm{mM}$, and the initial velocities determined (Fig. 8). At $0.3 \mathrm{mM}$ the relative velocities (\%) to synthesize the corresponding mev- $p_{n} A$ derivatives were for: far-PPP, $100 \%$ or $25.1 \pm 0.9 \mathrm{mU} / \mathrm{mg}$ ); iso-PPP, 89\%; ger-PPP, $78 \%$; isoPP, 17\%); dim-PP, $14 \%$; far-PP, $7 \%$ and ger-PP, $2 \%$. Inhibition (\%) of the activity by $0.8 \mathrm{mM}$ substrate vs. $0.3 \mathrm{mM}$ was also observed with far-PPP (81\% ) and far-PP (50\%) (Fig. 8).

For the $V_{\text {max }}, K_{m}, K_{\text {cat }}$ and $K_{\text {cat }} / K_{m}$ values calculated for T4 DNA ligase and the mevalonate compounds see Table 3. Again, the maximum catalytic efficiency $\left(K_{\text {cat }} / K_{m}\right)$ was obtained for far-PPP as a substrate. In general, the efficacy of T4 DNA ligase to synthesize mev- $p_{n} A$ derivatives is better than with T4 RNA ligase (compare the $K_{\text {cat }} / K_{m}$ values for both enzymes in Tables 2 and 3. 


\subsection{Synthesis of mevalonate derivatives of ATP by other ligases}

Luciferase, acetyl- and acyl-CoA synthetases, and the ubiquitin activating enzyme (E1), previously assayed in the synthesis of both (di)nucleoside polyphosphates and ATP derivatives of bisphosphonates [18, 22], were also tested for the synthesis of mev- $p_{n} A$ derivatives. From these enzymes, luciferase was the only one able to catalyze the synthesis of these derivatives. As previously known, luciferase $(E)$, in the presence of $D$ luciferin and ATP, forms the complex E-luciferin-AMP, the AMP moiety may be donated to nucleosides containing at least a tripolyphosphate chain, and the synthesis of dinucleoside polyphosphates occurs (Table 1, reactions 1 , 2) [18]. However when the ATP concentration in the assay is very low $(\mu \mathrm{M})$, the enzyme behaves as an ATPase liberating $\operatorname{AMP}[29,30]$. The synthesis of ATP mevalonate derivatives was approached here, incubating luciferase in the presence of $0.02 \mathrm{mM}\left[\alpha^{32} \mathrm{P}\right] \mathrm{ATP}$ and iso-PPP, far-PPP or ger-PPP at $0.3 \mathrm{mM}$ each (Fig. 9, A); a control in the absence of added substrate was run in parallel. After 20 min incubation, the reaction mixtures were treated with alkaline phosphatase. In addition to an important amount of AMP and a minor amount of $\mathrm{Ap}_{4} \mathrm{~A}$, the synthesis of the corresponding ATP derivatives was also observed. Formation of adenosine $5^{\prime}$-tetraphosphate $\left(p_{4} A\right)$ was detected with far-PPP as substrate, revealing the occurrence of free tripolyphosphate in this commercial preparation. The radioactive spots corresponding to the presumptive mev-ppppA were not sensitive to alkaline phosphatase as shown in Fig. 9, B and sensitive to phosphodiesterase, yielding AMP as one of the products (results not shown). A similar experiment using iso-PP as substrate is shown Fig. 9, C. The iso-pppA 
synthesized was not affected by treatment with alkaline phosphatase. The initial velocities calculated for the synthesis of the ATP derivatives shown in Fig. 9 were for: iso-PPP (2.0 mU/mg); far-PPP (1.8 mU/mg); ger-PPP (3.1 $\mathrm{mU} / \mathrm{mg})$ and iso-PP $(0.16 \mathrm{mU} / \mathrm{mg})$. Luciferase prefers the triphosphate derivatives of the compounds of mevalonate pathway, equally as it prefers nucleosides with a terminal $P_{3}$ over those with a terminal $P_{2}$, as substrates for the synthesis of dinucleoside polyphosphates [18].

In our hands, the other ligases tested, i.e. acetyl-CoA synthetase, acyl-CoA synthetase, and the ubiquitin activating enzyme E1 did not catalyze the synthesis of ATP derivatives with any one of the mevalonate compounds here mentioned.

\section{Discussion}

Our previous work on the synthesis of dinucleoside polyphosphates [18] and on ATP derivatives of bisphosphonates catalyzed by ligases [8, 9], and the finding by Mönkkönen of the occurrence of isopentenyltriphosphoadenosine (Apppl, here iso-pppA) in osteoclasts cells treated with bisphosphonates [16], prompted us to study the synthesis of ATP derivatives (mev-pppA and mev-ppppA) by several ligases. About the potential relationship between the effect of bisphosphonates both on the synthesis of these compounds in particular and on osteoclasts in general, two main possibilities can be envisaged.

A. Bisphosphonates could stimulate the synthesis of mev-pppA considering simply that, if BPs accumulate in bone tissues inhibiting some of the 
enzymes of the mevalonate pathway (Fig. 1), an increase in the concentration of metabolites upstream the inhibited step would take place, and consequently, an increase of the synthesis of the mevalonate derivatives (mev-pppA) catalyzed by ligases, could occur (Table 1). Recently, several laboratories have studied the interaction of alendronate, ibandronate, risedronate and zoledronate (bisphosphonates of the second and third generation, all N-BPs), with crystallized human farnesyl pyrophosphate synthetase (Fig. 1) with similar and complementary results [31-33]. The nitrogen atom of N-BPs interacts with the Thr-201 and Lys-200 of the enzyme, located in its carbocation-binding site favoring the position of BPs in the dimethylallyl/geranyl diphosphate ligand pocket [32]. Those NBPs bind to this site through a trinuclear metal center similar to that formed with the terminal pyrophosphate of some compounds of the mevalonate pathway [33]. In addition, the isopentenyl diphosphate accumulated (due to the inhibition of the enzyme), rather than competing for and displacing the $\mathrm{BP}$, binds and stabilizes the enzyme-N-BP complex, forming a ternary complex. This fact contributes to the exceptional in vivo efficacy of the N-BP drugs [33], and could explain the preferential synthesis of iso-pppA reported by Mönkkönen [16]. At any rate, both the $\mathrm{N}$-atom and the bisphosphonate chain itself are critical for the inhibitory effect of N-BP on this enzyme. In this context, we may recall that the components of the mevalonate pathway comprise the highest gathering of consecutive compounds with a terminal pyrophosphate in any known metabolic pathway in mammals, what could be another characteristics for the preferential action of bisphosphonates in this pathway (Fig. 1). It may also be recalled that some BPs are substrates 
for the synthesis of ATP derivatives of the type $A p p C(R 1)(R 2) p$ catalyzed by ligases [5-9]; in principle, these ATP derivatives could interfere with the activity of enzymes using ATP as substrate. To this group belong at least 150 enzymes with transferase activity and more than 90 with ligase activity (see Enzyme Nomenclature). Probably most of these ATP derivatives could act on these enzymes as competitive inhibitors (although other type of inhibition could also be contemplated) with variable efficacy. In this regard it is worthy noting that, the mevalonate pathway presents the exceptional characteristic of holding three enzymes (2 kinases and 1 decarboxilase) requiring ATP and operating in sequence (Fig. 1). The concatenation of these steps could make the mevalonate pathway specially exposed to the effect of the BP derivatives of ATP.

B. The synthesis of mev-pppA is partially or totally unrelated to the effect of bisphosphonates. The occurrence of mev-pppA in liver and other tissues cannot be disregarded in view of the quantity of ligases potentially able to transfer the AMP moiety of the E-AMP or EX-AMP complexes to compounds with a terminal di or triphosphate [18]. Examples of this possibility are here reported for the case of T4 RNA ligase, T4 DNA ligase and luciferase. Moreover, the synthesis of compounds with inner phosphate(s) and containing at least a terminal nucleotide (AMP, GMP, UMP or CMP, depending on the ligase involved) can be equally pondered. These compounds can be considered as metabolic by-products, with no metabolic significance, whose natural destiny is to be eliminated by specific or unspecific enzymes and, because of the low concentration reached in the cell, have passed unnoticed. Experiments performed years ago in our 
laboratory showed the existence of a number of still unknown nucleotides with these peculiarities in rat liver [34]. However, in our view, compounds present at low concentration in tissues and containing inner phosphate(s) are also candidates to be regulatory molecules [35]. In the particular case of the mevalonate derivative, iso-pppA, this compound inhibited the ADP/ATP translocase and caused apoptosis in osteoclasts [16]. The possibility that other mev-pppA derivatives could also have regulatory effects remains an open question.

\section{Acknowledgements}

This work was supported by grants from Dirección General de Investigación Científica y Técnica (BFU 2006-04307/BMC and BFU 2008-00666/BMC). We thank Antonio Fernández and Sandra Morillo (Erasmus student from ENCPB, Paris, France) for technical assistance. J. E. F. T. and J. A. D. C. S. were Erasmus students from the Faculdade de Farmacia, Universidade do Porto, Portugal.

\section{REFERENCES}

[1] Bartl R, Frisch B, von Tresckow E, Bartl C. Bisphosphonates in Medical Practice. Berlin: Springer-Verlag, 2007.

[2] Lin JH. Bisphosphonates: a review of their pharmacokinetic properties. Bone 1996;18:75-85.

[3] Chen T, Berenson J, Vescio R, Swift R, Gilchick A, Goodin S, et al. Pharmacokinetics and pharmacodynamics of zoledronic acid in cancer patients with bone metastases. J Clin Pharmacol 2002;42:1228-36.

[4] Skerjanec A, Berenson J, Hsu C, Major P, Miller WH, Jr., Ravera C, et al. The pharmacokinetics and pharmacodynamics of zoledronic acid in cancer patients with varying degrees of renal function. J Clin Pharmacol 2003;43:154-62. 
[5] Klein G, Martin JB, Satre M. Methylenediphosphonates, a metabolite poison in Dictyostelium discoideum. ${ }^{31} \mathrm{P}$ NMR evidence for accumulation of adenosine $5^{\prime}-(\beta, \gamma-$ Methylenetriphosphate $)$ and diadenosine $5^{\prime}-5^{\prime \prime \prime}-\left(\mathrm{P}^{2}, \mathrm{P}^{3}-\right.$ methylenetetraphosphate $)$. Biochemistry 1988;27:1897-901.

[6] Rogers MJ, Brown RJ, Hodkin V, Blackburn GM, Russell RG, Watts DJ. Bisphosphonates are incorporated into adenine nucleotides by human aminoacyl-tRNA synthetase enzymes. Biochem Biophys Res Commun 1996;224:863-9.

[7] Rogers MJ. New insights into the molecular mechanisms of action of bisphosphonates. Curr Pharm Des 2003;9:2643-58.

[8] Günther Sillero MA, de Diego A, Silles E, Pérez-Zúñiga F, Sillero A. Synthesis of bisphosphonate derivatives of ATP by T4 RNA ligase. FEBS Lett 2006;580:5723-7.

[9] Günther Sillero MA, de Diego A, Pérez-Zúñiga FJ, Sillero A. Synthesis of bisphosphonate derivatives of ATP by T4 DNA ligase, ubiquitin activating enzyme (E1) and other ligases. Biochem Pharmacol 2008;75:1959-65.

[10] Reszka AA, Rodan GA. Bisphosphonate mechanism of action. Curr Rheumatol Rep 2003;5:65-74.

[11] Bergstrom JD, Bostedor RG, Masarachia PJ, Reszka AA, Rodan G. Alendronate is a specific, nanomolar inhibitor of farnesyl diphosphate synthase. Arch Biochem Biophys 2000;373:231-41.

[12] Rogers MJ. New insights into the molecular actions of nitrogencontaining bisphosphonates. Haematological Reports 2006;2:24-5.

[13] Amin D, Cornell SA, Gustafson SK, Needle SJ, Ullrich JW, Bilder $\mathrm{GE}$, et al. Bisphosphonates used for the treatment of bone disorders inhibit squalene synthase and cholesterol biosynthesis. J Lipid Res 1992;33:1657-63.

[14] Fisher JE, Rogers MJ, Halasy JM, Luckman SP, Hughes DE, Masarachia PJ, et al. Alendronate mechanism of action: geranylgeraniol, an intermediate in the mevalonate pathway, prevents inhibition of osteoclast formation, bone resorption, and kinase activation in vitro. Proc Natl Acad Sci U S A 1999;96:133-8.

[15] Roelofs AJ, Thompson K, Gordon S, Rogers MJ. Molecular mechanisms of action of bisphosphonates: current status. Clin Cancer Res 2006;12:6222s-30s.

[16] Mönkkönen H, Auriola S, Lehenkari P, Kellinsalmi M, Hassinen IE, Vepsalainen J, et al. A new endogenous ATP analog (Apppl) inhibits the mitochondrial adenine nucleotide translocase (ANT) and is responsible for the apoptosis induced by nitrogen-containing bisphosphonates. British journal of pharmacology 2006;147:437-45.

[17] Lehenkari PP, Kellinsalmi M, Napankangas JP, Ylitalo KV, Mönkkönen J, Rogers MJ, et al. Further insight into mechanism of action of clodronate: inhibition of mitochondrial ADP/ATP translocase by a nonhydrolyzable, adenine-containing metabolite. Molecular pharmacology 2002;61:1255-62.

[18] Sillero A, Günther Sillero MA. Synthesis of dinucleoside polyphosphates catalyzed by firefly luciferase and several ligases. Pharmacol Ther 2000;87:91-102. 
[19] Ortiz B, Sillero A, Günther Sillero MA. Specific synthesis of adenosine (5')tetraphospho( $\left.5^{\prime}\right)$ nucleoside and adenosine(5')oligophospho( $\left.5^{\prime}\right)$ adenosine $(n>4)$ catalyzed by firefly luciferase. Eur J Biochem 1993;212:263-70.

[20] Fontes R, Günther Sillero MA, Sillero A. Acyl coenzyme A synthetase from Pseudomonas fragi catalyzes the synthesis of adenosine 5'-polyphosphates and dinucleoside polyphosphates. J Bacteriol 1998;180:3152-8.

[21] Guranowski A, Günther Sillero MA, Sillero A. Adenosine 5'tetraphosphate and adenosine 5'-pentaphosphate are synthesized by yeast acetyl coenzyme A synthetase. J Bacteriol 1994;176:2986-90.

[22] Günther Sillero MA, de Diego A, Silles E, Sillero A. Synthesis of (di)nucleoside polyphosphates by the ubiquitin activating enzyme E1. FEBS Lett 2005;579:6223-9.

[23] McLennan AG, editor. $\mathrm{Ap}_{4} \mathrm{~A}$ and other dinucleoside polyphosphates. Boca Raton, Florida: CRC Press, 1992.

[24] McLennan AG, Barnes LD, Blackburn GM, Brenner C, Guranowski $A$, Miller $A D$, et al. Recent progress in the study of the intracellular functions of diadenosine polyphosphates. Drug Development Res 2001;52:249-59.

[25] Delicado EG, Miras-Portugal MT, Carrasquero LM, León D, PérezSen R, Gualix J. Dinucleoside polyphosphates and their interaction with other nucleotide signaling pathways. Pflugers Arch 2006;452:563-72.

[26] Holler E. The chemistry of dinucleoside polyphosphates. In: McLennan $A G$, editor. $\mathrm{Ap}_{4} \mathrm{~A}$ and other dinucleoside polyphosphates. Boca Raton, Florida: CRC Press, 1992. p. 9-28.

[27] Madrid O, Martin D, Atencia EA, Sillero A, Günther Sillero MA. T4 DNA ligase synthesizes dinucleoside polyphosphates. FEBS Lett 1998;433:283-6.

[28] Atencia EA, Madrid O, Günther Sillero MA, Sillero A. T4 RNA ligase catalyzes the synthesis of dinucleoside polyphosphates. Eur J Biochem 1999;261:802-11.

[29] DeLuca M, McElroy WD. The hydrolase properties of firefly luciferase. Biochem Biophys Res Commun 1965;18:836-42.

[30] Garrido S, Zaera E, Torrecilla A, Sillero A, Günther Sillero MA. Labeled adenosine $\left(5^{\prime}\right)$ tetraphospho( $\left.5^{\prime}\right)$ adenosine $\left(\mathrm{Ap}_{4} \mathrm{~A}\right)$ and adenosine $\left(5^{\prime}\right)$ tetraphospho $\left(5^{\prime}\right)$ nucleoside $\left(\mathrm{Ap}_{4} \mathrm{~N}\right)$. Synthesis with firefly luciferase. J Biochem Biophys Methods 1995;30:191-8.

[31] Hosfield DJ, Zhang Y, Dougan DR, Broun A, Tari LW, Swanson RV, et al. Structural basis for bisphosphonate-mediated inhibition of isoprenoid biosynthesis. J Biol Chem 2004;279:8526-9.

[32] Kavanagh KL, Guo K, Dunford JE, Wu X, Knapp S, Ebetino FH, et al. The molecular mechanism of nitrogen-containing bisphosphonates as antiosteoporosis drugs. Proc Natl Acad Sci U S A 2006;103:782934.

[33] Rondeau JM, Bitsch F, Bourgier E, Geiser M, Hemmig R, Kroemer $\mathrm{M}$, et al. Structural basis for the exceptional in vivo efficacy of bisphosphonate drugs. ChemMedChem 2006;1:267-73. 
[34] Buitrago F, Canales J, Günther Sillero MA, Sillero A. Occurrence of a novel nucleotide, Zpp5'A2' $p$, in rat liver extracts. Biochem Int 1988;16:175-84.

[35] Sillero MAG, Villalba R, Moreno A, Quintanilla M, Lobatón CD, Sillero A. Dinucleosidetriphosphatase from rat liver. Purification and properties. Eur J Biochem 1977;76:331-7.

\section{LEGEND TO FIGURES}

Fig. 1. Components of the mevalonate pathway, its precursors and some metabolic connections. The metabolic pathway from acetyl-CoA to mevalonate-5-phospahte, and the implicated enzymes (1-5) are indicated in the figure. The enzymes are: 1, acetyl-CoA acetyltransferase (EC 2.3.1.9); 2, hydroxymethylglutaryl-CoA synthase (EC 4.1.3.5); 3, 3hydromethylglutaryl-CoA reductase, (EC 1.1.1.34); 4, mevalonate kinase (EC 2.7.1.36); 5, phosphomevalonate kinase (EC 2.7.4.2). Note that the three consecutive steps catalyzed by enzymes (4), (5) and (A), consume three moles of ATP. The inset in the figure comprises the compounds of the mevalonate pathway and the enzymes $(A-G)$ involved: $A$, diphosphomevalonate decarboxylase, (EC 4.1.1.33); B, isopentenyldiphosphate D-isomerase, (EC 5.3.3.2); C, dimethylallyltranstransferase, (EC 2.5.1.1); D, geranyltranstransferase (farnesyl-diphosphate synthase), (EC 2.5.1.10); E, farnesyltranstransferase, (EC 2.5.1.29); F, farnesyldiphosphate farnesyltransferase, (EC 2.5.1.21). Note as the two activities catalyzed by the human farnesyl pyrophosphate synthetase (see the text, [31-33]) are registered in the Enzyme Commission as carried out by the enzymes with entries EC 2.5.1.1 and EC 2.5.1.10. To emphasize the occurrence of pyrophosphate in all the compounds of the cycle, this moiety 
has been marked out $(\bullet)$. Some of the great variety of compounds

synthesized from those metabolites, and essential for cell function, are encircled by a doted line.

Fig. 2. Synthesis of isopentenyl-triphospho( $\left.5^{\prime}\right)$ adenosine (iso-pppA) from isopentenyl diphosphate and ATP, catalyzed by T4 RNA ligase. The reaction was carried out in the presence of $0.02 \mathrm{mM}\left[\alpha^{32} \mathrm{P}\right] \mathrm{ATP}(0.4 \mu \mathrm{Ci}), 1$ $\mathrm{mM}$ iso-PP, $20 \mathrm{U}$ enzyme and other components as specified in Materials and methods (lanes 3, 5 and 7). Two control reactions (with no added enzyme (lane 1) and with no added isopentenyl-PP (lanes 2, 4 and 6) were run in parallel. Samples were taken after 15, 30 and 60 min incubation and subjected to TLC. After 60 min incubation, the reaction mixtures containing enzyme (lanes 6 and 7 ) were treated with $1 \mu \mathrm{l}(1 \mathrm{U})$ of shrimp alkaline phosphatase (AP) (lanes 8 and 9). Once the phosphatase was denatured by heating at $90^{\circ} \mathrm{C}$ for $6 \mathrm{~min}$, the reaction mixture was treated with snake venom phosphodiesterase (SVP) (lanes 10 and 11).

Fig. 3. Synthesis and characterization of isopentenyltetraphospho(5')adenosine (iso-ppppA) from isopentenyl triphosphate and ATP, catalyzed by T4 RNA ligase. Analysis by HPLC.

Reaction mixtures $(0.08 \mathrm{ml})$ containing $60 \mathrm{U}$ T4 RNA ligase, $0.3 \mathrm{mM}$ ATP and $0.4 \mathrm{mM}$ Iso-PPP (other components as indicated in Material and methods) were incubated for $6 \mathrm{~h}$ (b) and $20 \mathrm{~h}$ (c) and aliquots analyzed by HPLC. The rest of the reaction mixture was treated with $1 \mu \mathrm{l}(1 \mathrm{U})$ of shrimp 
alkaline phosphatase (for $2 \mathrm{~h}$ at $37^{\circ} \mathrm{C}$ ) (d) and, after inactivation of the phosphatase by heating, further treated with snake venom phosphodiesterase (e). A control reaction with no added enzyme is shown in (a).

Fig. 4. Synthesis of ATP derivatives of compounds of the mevalonate pathway $\left(\operatorname{mevp}_{n} A\right)$, catalyzed by T4 RNA ligase. The indicated compounds were tested as substrates of T4 RNA ligase at two different concentrations: $0.3 \mathrm{mM}$ (upper panel) and $0.8 \mathrm{mM}$ (lower panel), in the presence of 0.02 $\mathrm{mM}\left[\alpha^{32} \mathrm{P}\right] \mathrm{ATP}(0.4 \mu \mathrm{Ci})$ and $16 \mathrm{U}$ enzyme. Controls with no added substrate were run in parallel (first lanes).

Fig. 5. Synthesis of the ATP derivatives of compounds of the mevalonate pathway $\left(\operatorname{mevp}_{n} \mathrm{~A}\right)$, catalyzed by T4 RNA ligase. Relative activities. The substrates were assayed at two different concentrations: $0.3 \mathrm{mM}$ or $0.8 \mathrm{mM}$, as described in Fig. 4. The ordinate scale reflects enzyme activity (initial velocity) calculated as $\mathrm{mU} / \mathrm{mg}$ of protein.

Fig. 6. Inhibition by excess of substrate, of the synthesis of far-pppA and far-ppppA, catalyzed by T4 RNA ligase, The reaction mixtures $(0.02 \mathrm{ml})$ contained $0.02 \mathrm{mM}\left[\alpha^{32} \mathrm{P}\right] \mathrm{ATP}(0.4 \mu \mathrm{Ci})$, far-PP and $20 \mathrm{U}$ enzyme $(\mathrm{A})$, or far-PPP and $13 \cup$ enzyme (C). Other components and analysis by TLC as indicated in Materials and methods. The corresponding derivatives formed in the assay (pmoles), were calculated and are represented in (B) and (D). 
Fig. 7. Synthesis of isopentenyl-triphospho(5')adenosine (iso-pppA) catalyzed by T4DNA ligase. The reaction was carried out in the presence of $0.02 \mathrm{mM}\left[\alpha^{32} \mathrm{P}\right] A T P(0.4 \mu \mathrm{Ci}), 1 \mathrm{mM}$ iso-PP, $2 \mathrm{U}$ enzyme, and other components as specified in Materials and methods (lanes 3, 5, 7). Two control reactions (with no added enzyme (lane 1) and with no added iso-PP (lanes 2, 4 and 6) were run in parallel. Samples were taken after 15, 30 and 60 min incubation and subjected to TLC. After 60 min incubation, the reaction mixtures containing enzyme (lanes 6 and 7 ) were treated first with alkaline phosphatase (AP) (lanes 8 and 9) and, after inactivation of the phosphatase, treated with snake venom phosphodiesterase (SVP) (lanes 10 and 11).

Fig. 8. Synthesis of the ATP derivatives of compounds of the mevalonate pathway $\left(\operatorname{mevp}_{n} \mathrm{~A}\right)$ catalyzed by T4 DNA ligase. Relative activities. The substrates were assayed in the presence of $0.02 \mathrm{mM}\left[\alpha^{32} \mathrm{P}\right] \mathrm{ATP}(0.4 \mu \mathrm{Ci})$ at two different concentrations: $0.3 \mathrm{mM}$ or $0.8 \mathrm{mM}$, and $2 \mathrm{U}$ enzyme. The ordinate scale reflects enzyme activity (initial velocity) calculated as $\mathrm{mU} / \mathrm{mg}$ of protein.

Fig. 9. Synthesis of ATP derivatives of the mevalonate pathway compounds, catalyzed by firefly luciferase. The reaction mixtures contained $0.02 \mathrm{mM}\left[\alpha^{32} \Pi\right] \mathrm{AT \Pi}(0.4 \mu \mathrm{Ci})$, and $0.3 \mathrm{mM}$ iso-PPP, far-PPP or ger-PPP (A), or $0.4 \mathrm{mM}$ iso-PP (C), and $5 \mu \mathrm{g}$ enzyme. Controls in the absence of mev-compounds were carried out (lanes 1). Samples were taken after 20 
min incubation and subjected to TLC (A and $C)$. The reaction mixtures were further treated with alkaline phosphatase (see B and D). 


\section{2 acetyl-CoA}

(1).

Acetoacetyl-CoA

(2),

Hydroxymethylglutaryl-CoA

(3).

Mevalonate

(4), ATP

Mevalonate-5-P

(5) ATP

Aldosterone

Mevalonate $\bullet$

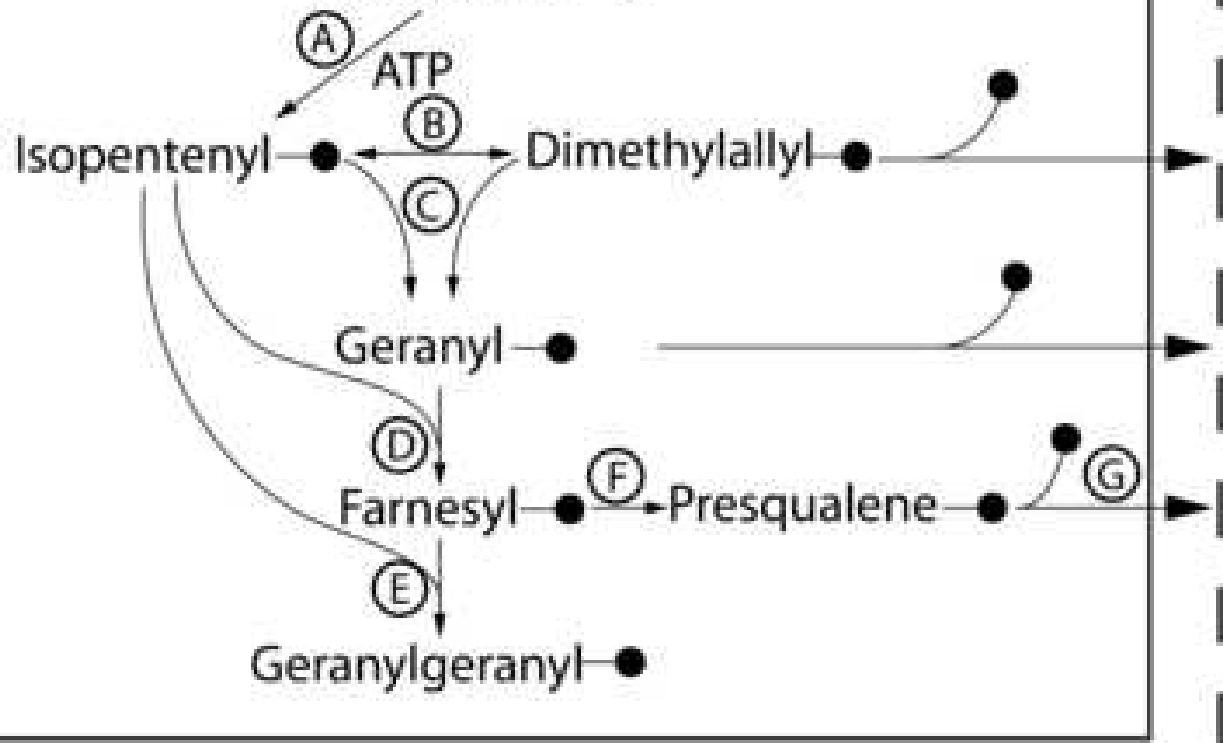

Bile acids

Cholesterol

Cortisone

Dolichol

Estrone

Farnesylated proteins

Geranyl-geranylated

proteins

Glucocorticoids

Progesterone

Steroids

Testosterone Ubiquinone

Fig. 1 

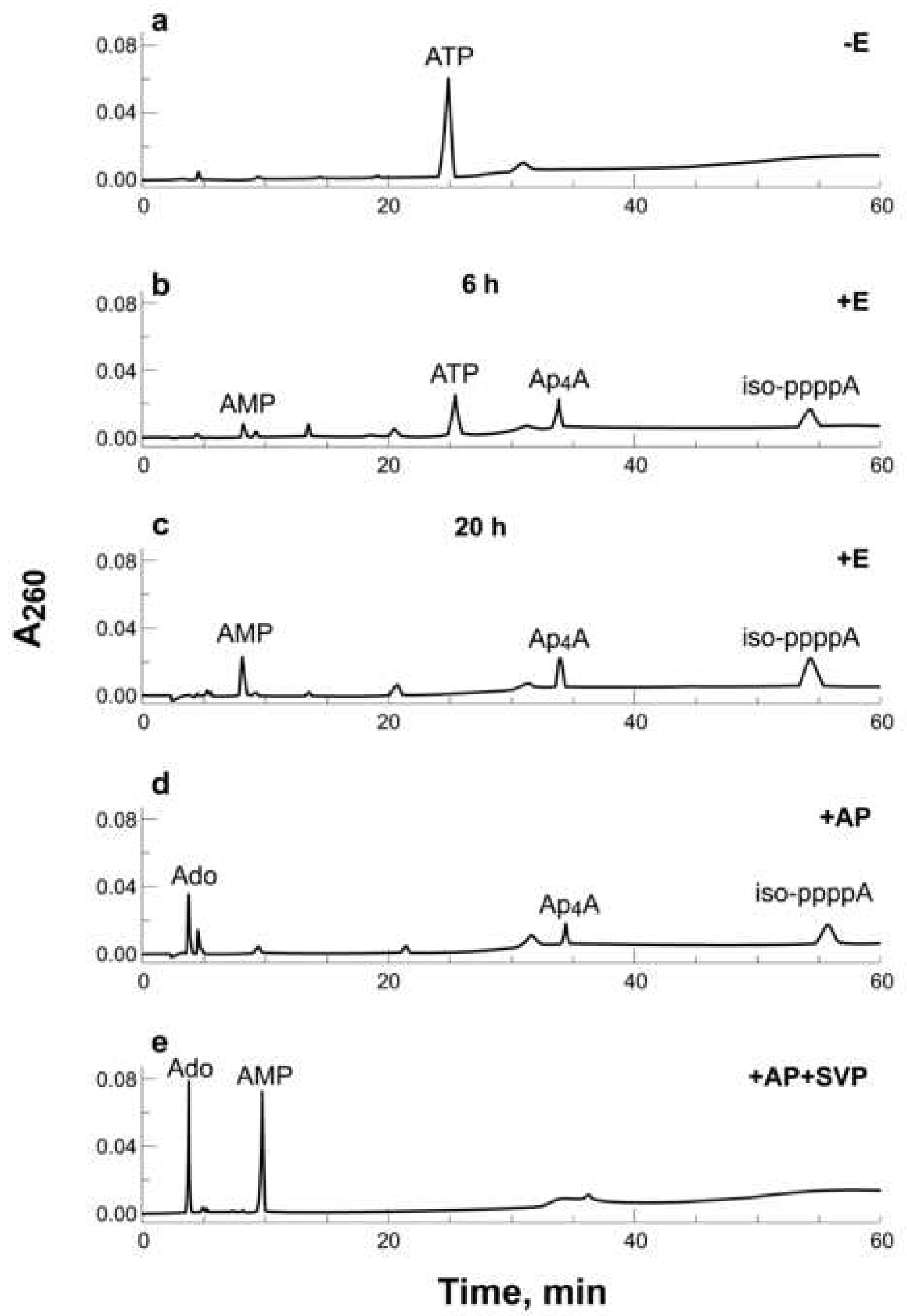

Fig3 

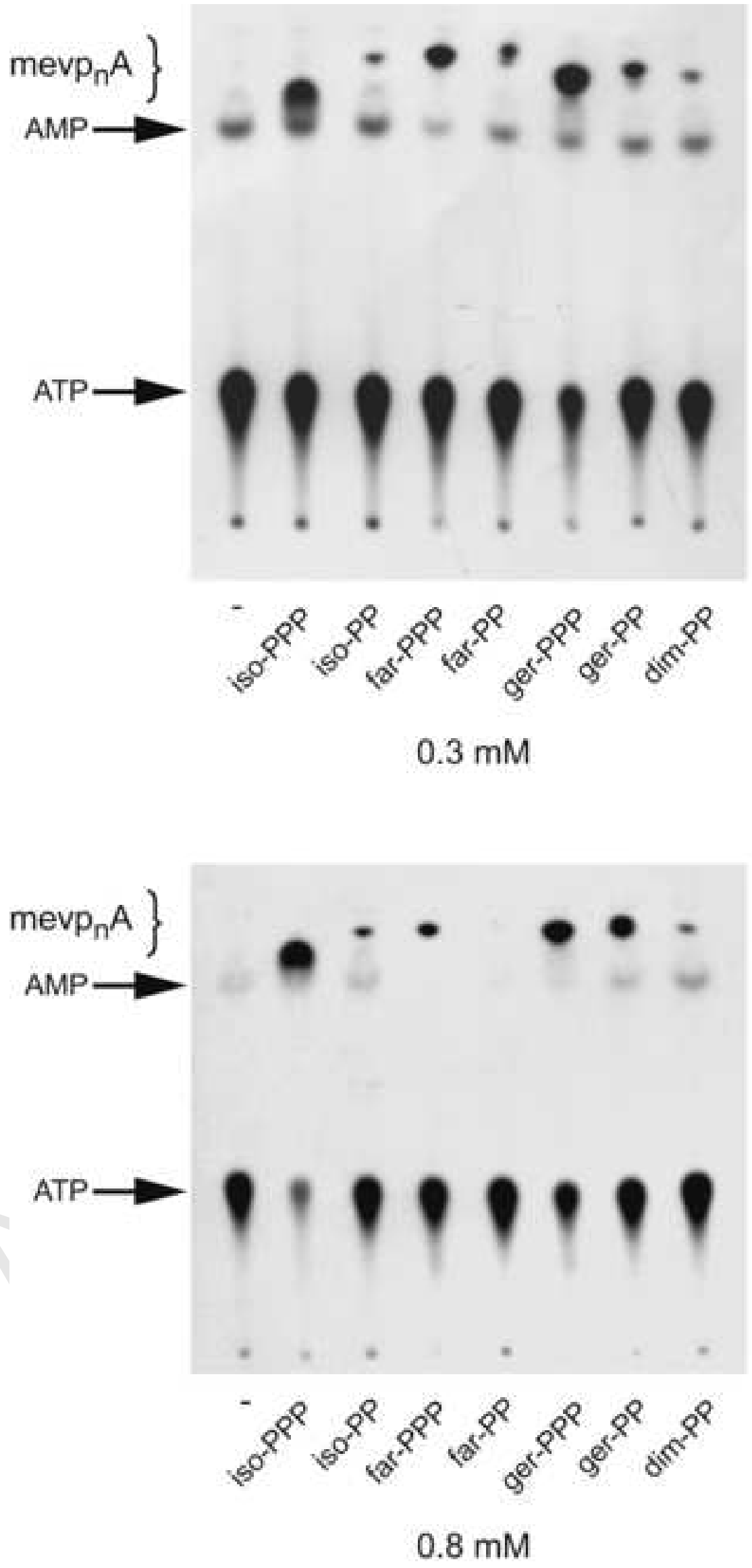

Fig.4 


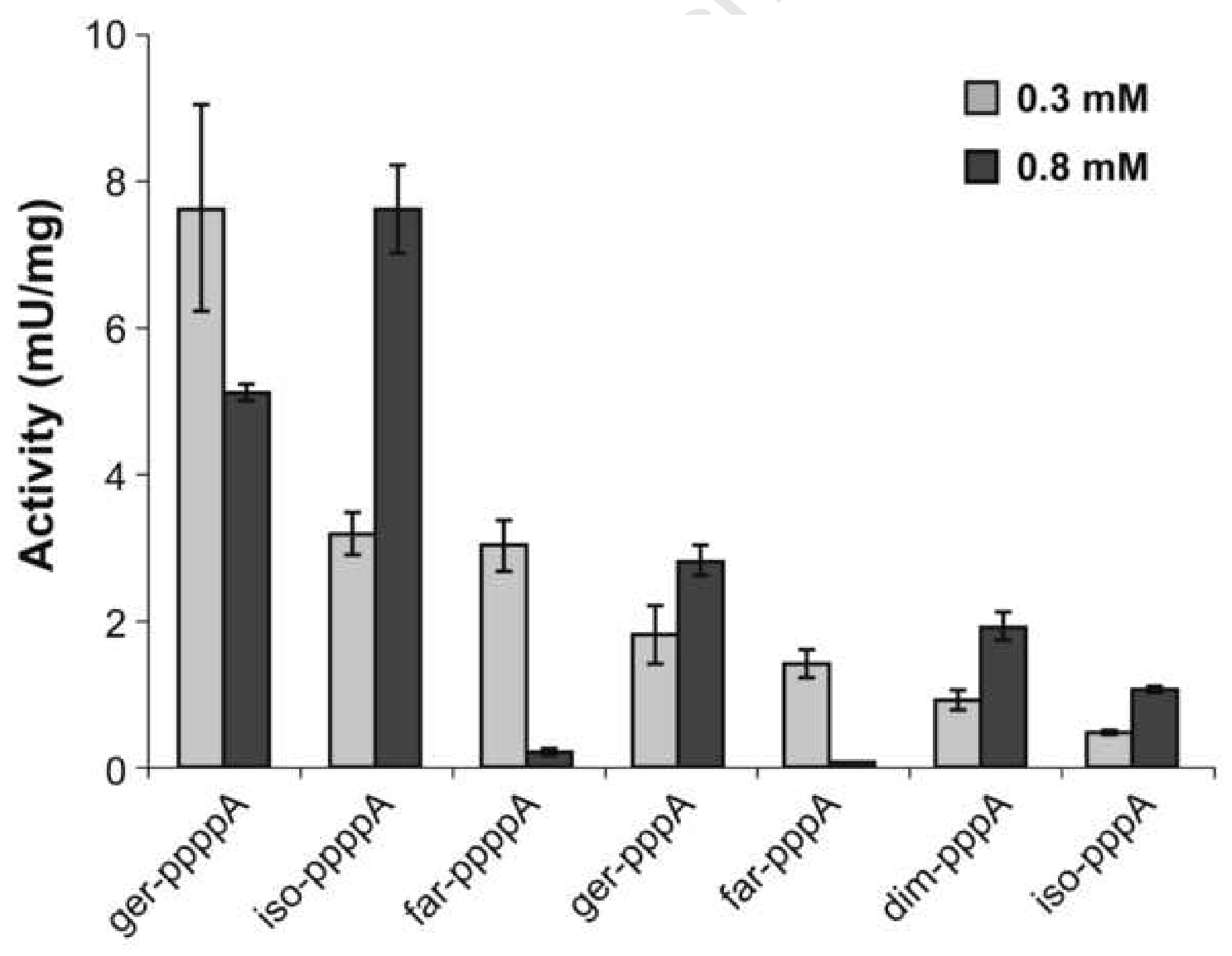

Figure 5 
A
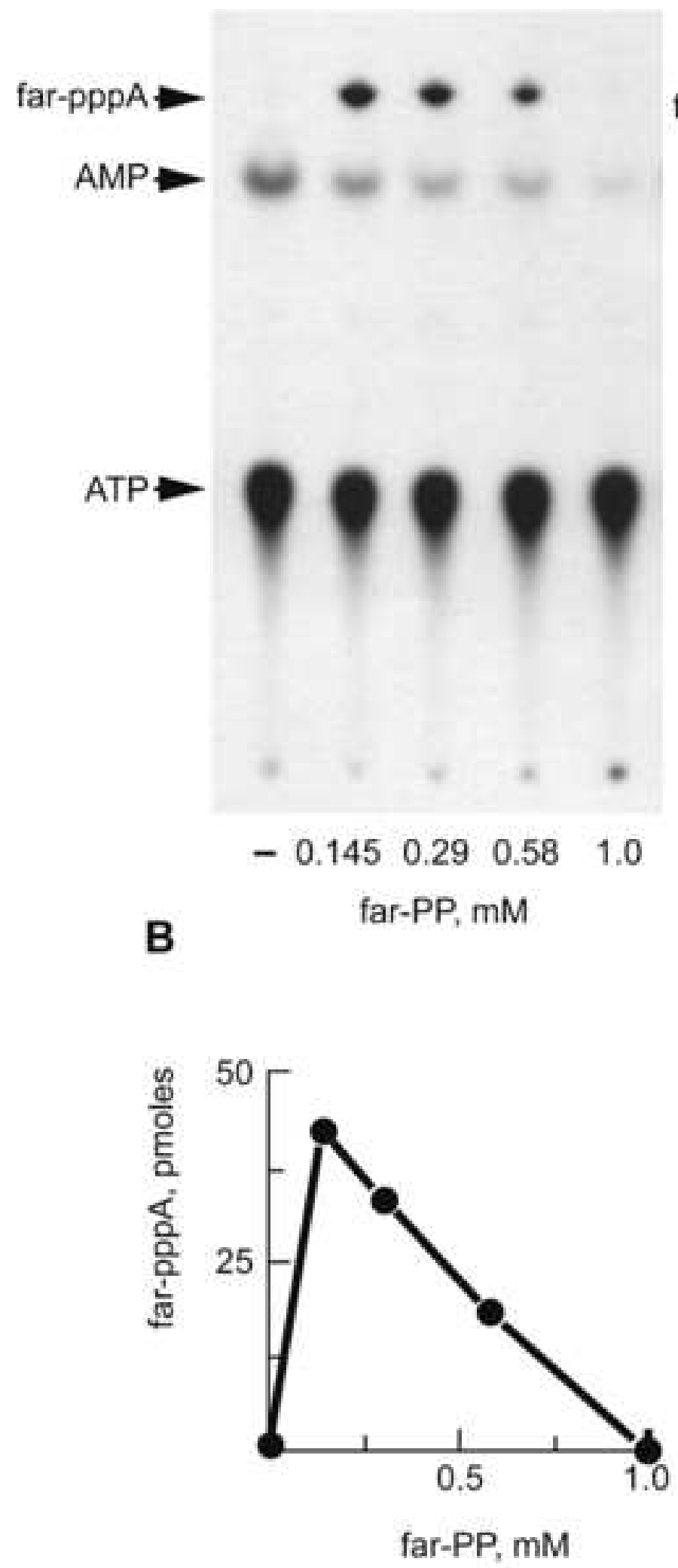

C

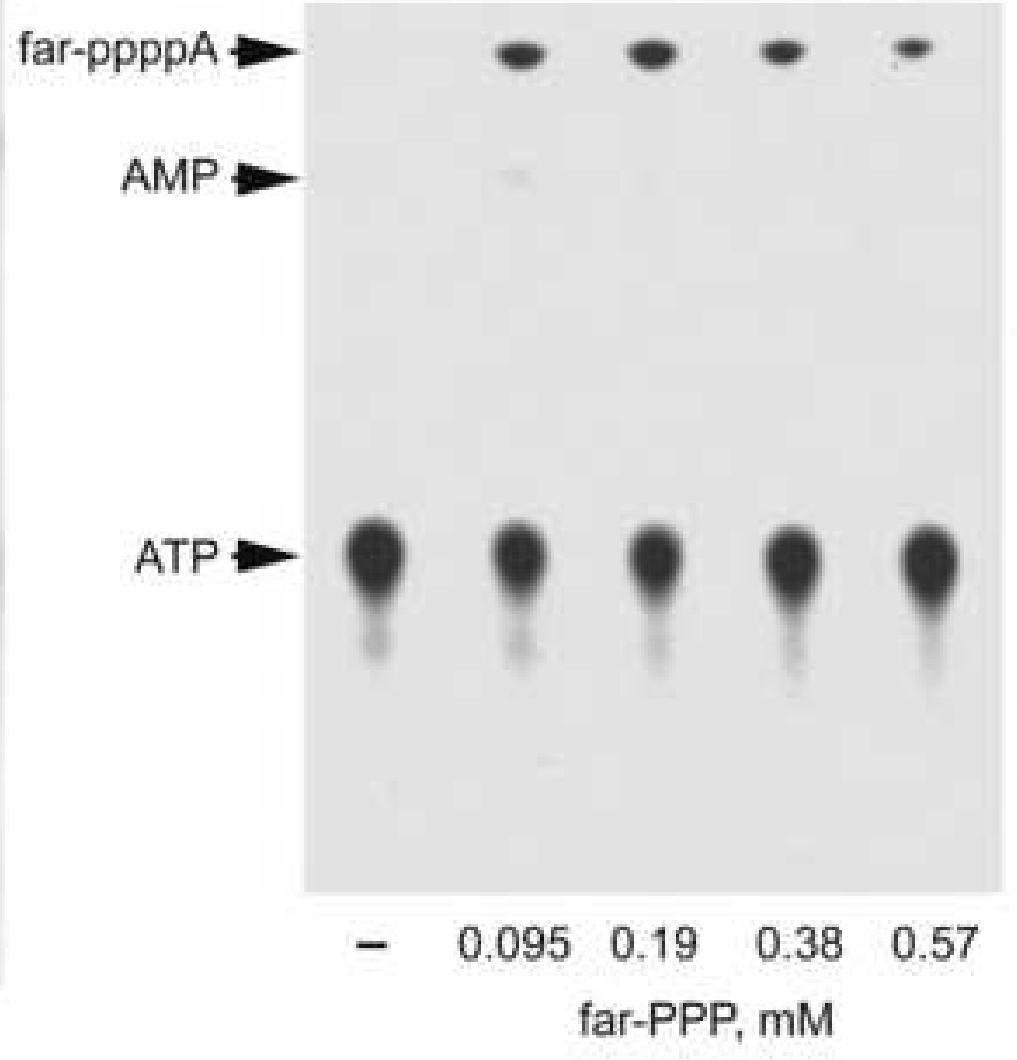

D

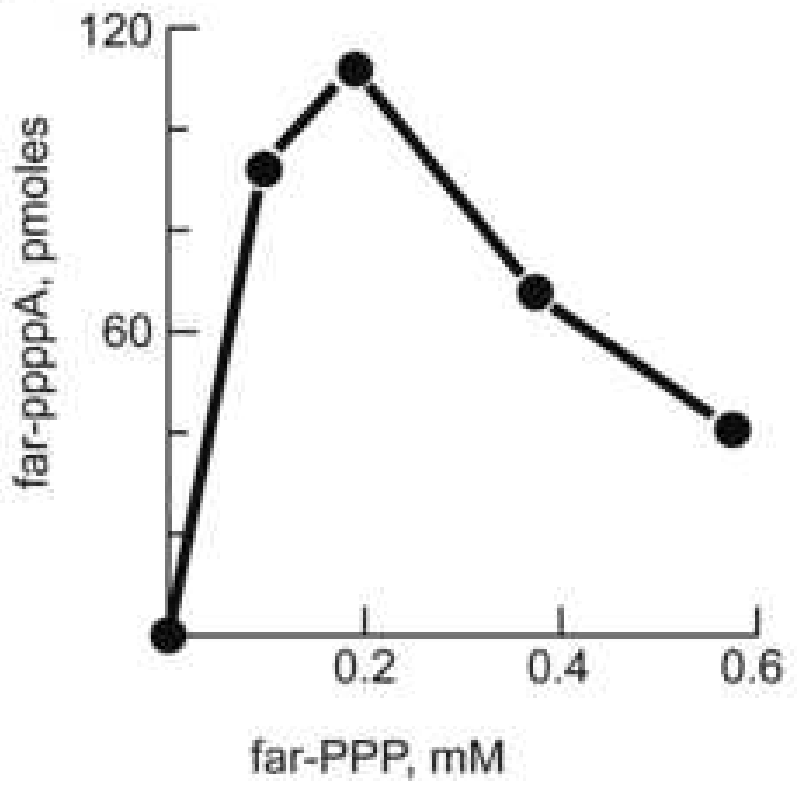

Fig.6

Page 30 of 36 


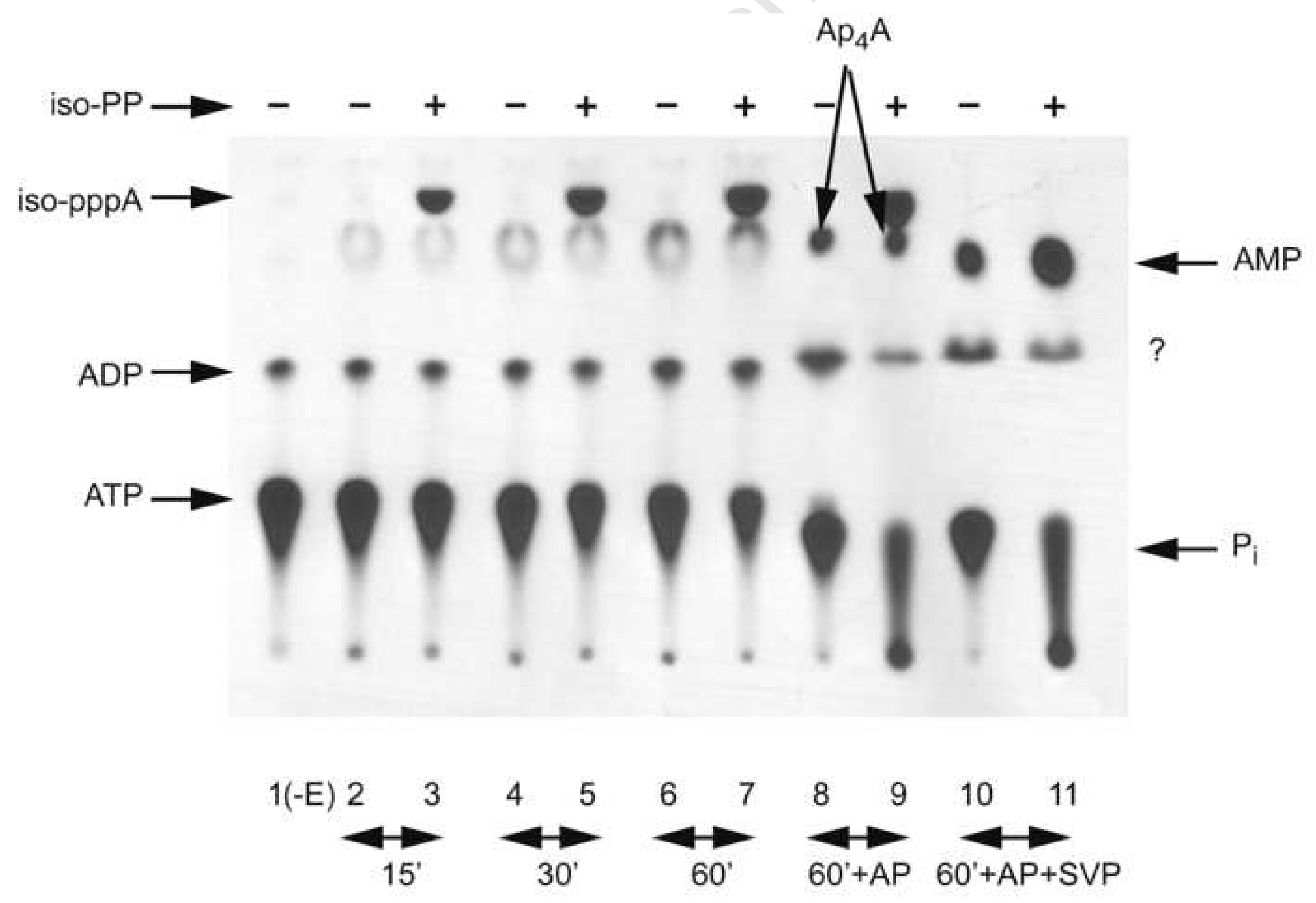

Fig. 7 


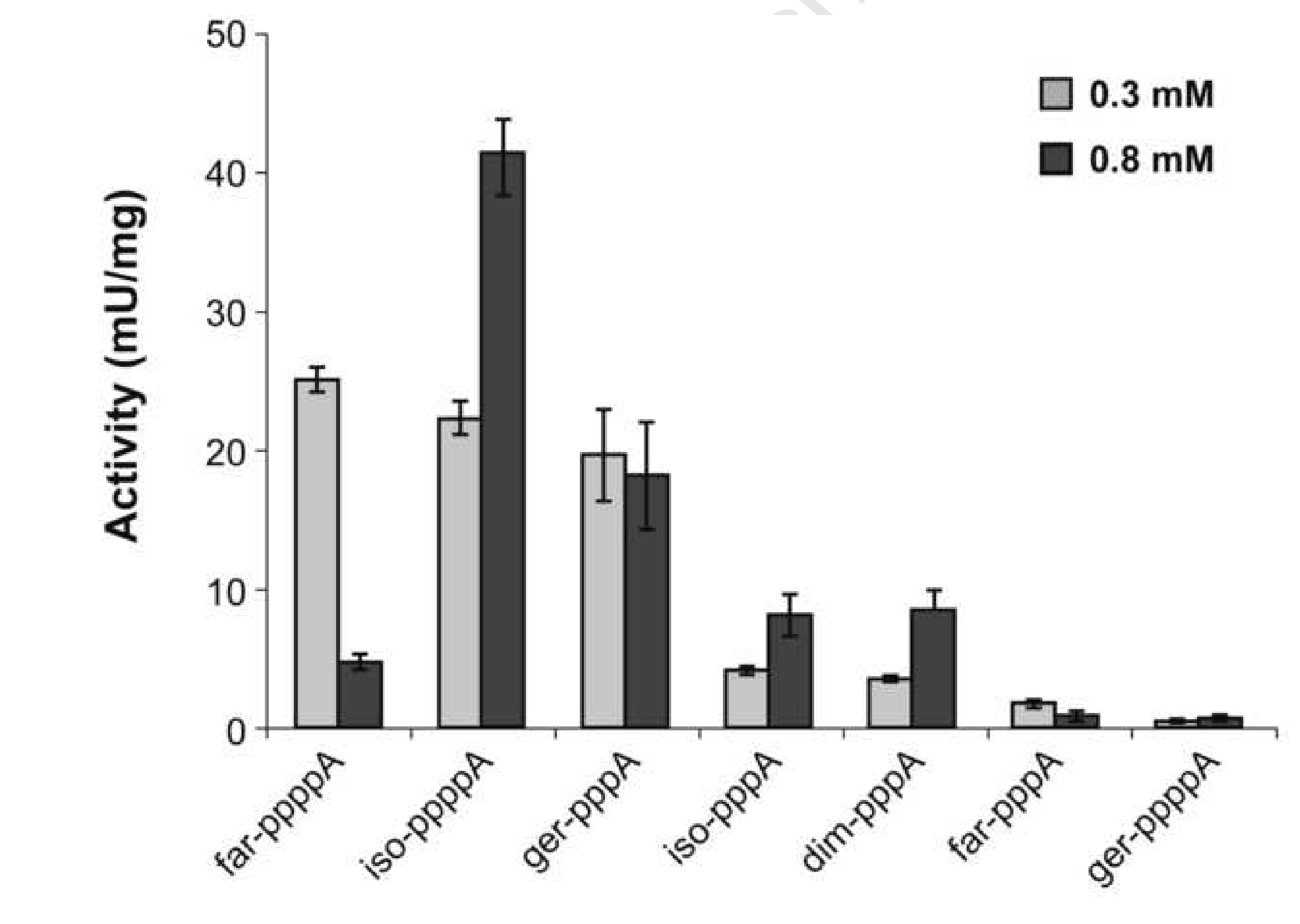

Figure 8 
Mevalonate derivatives containing a terminal pyrophosphate form a new family of compounds catalyzed by ligases. Potential relationship with bisphosphonates

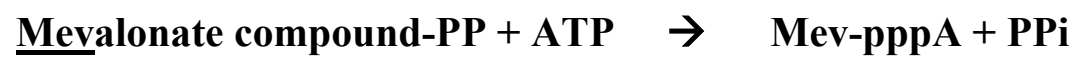




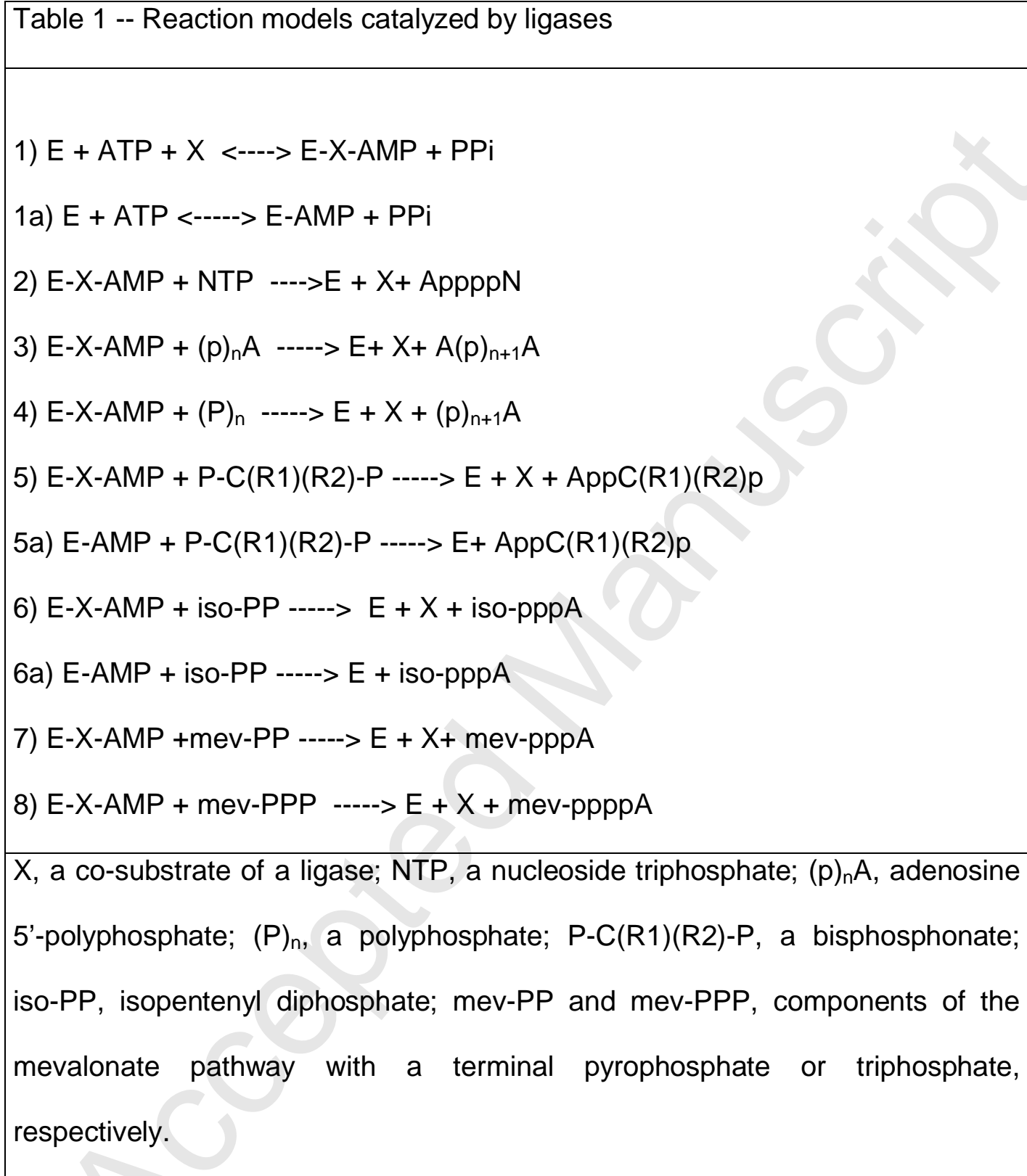

Table 2. $V_{\max }, K_{\mathrm{m}}$ and $K_{\text {cat }}$ values of T4 RNA ligase towards substrates of the mevalonate pathway

Substrate

$V_{\max }$
$(\mathrm{mU} / \mathrm{mg})$

$K_{\mathrm{m}}$
$(\mathrm{M})$

$K_{\text {cat }}$
$\left(\mathrm{s}^{-1}\right)$




\begin{tabular}{|l|l|l|l|l|}
\hline Farnesyl triphosphate & $16.0 \pm 1.5$ & $\begin{array}{l}0.07 \pm 0.01 \\
\times 10^{-3}\end{array}$ & $11.6 \times 10^{-3}$ & 166 \\
\hline Geranyl triphosphate & $16.6 \pm 0.6$ & $\begin{array}{l}0.23 \pm 0.02 \\
\times 10^{-3}\end{array}$ & $12.0 \times 10^{-3}$ & 52.2 \\
\hline Farnesyl diphosphate & $4.0 \pm 0.5$ & $\begin{array}{l}0.24 \pm 0.02 \\
\times 10^{-3}\end{array}$ & $2.9 \times 10^{-3}$ & 12.1 \\
\hline Geranyl diphosphate & $3.4 \pm 0.1$ & $\begin{array}{l}0.29 \pm 0.06 \\
\times 10^{-3}\end{array}$ & $2.5 \times 10^{-3}$ & 8.6 \\
\hline Isopentenyl triphosphate & $33.5 \pm 5.1$ & $\begin{array}{l}3.6 \pm 0.5 \\
\times 10^{-3}\end{array}$ & $24.0 \times 10^{-3}$ & 6.7 \\
\hline Dimethylallyl diphosphate & $3.7 \pm 0.4$ & $\begin{array}{l}0.86 \pm 0.34 \\
\times 10^{-3}\end{array}$ & $2.7 \times 10^{-3}$ & 3.1 \\
\hline Isopentenyl diphosphate & $6.2 \pm 0.3$ & $\begin{array}{l}4.9 \pm 1.4 \\
\times 10^{-3}\end{array}$ & $4.5 \times 10^{-3}$ & 0.9 \\
\hline
\end{tabular}

Table 3. $V_{\max }, K_{\mathrm{m}}$ and $K_{\mathrm{cat}}$ values of T4 DNA ligase towards substrates of the mevalonate pathway

\begin{tabular}{|l|l|l|l|l|}
\hline & $\begin{array}{l}V_{\max } \\
(\mathrm{mU} / \mathrm{mg})\end{array}$ & $\begin{array}{l}K_{\mathrm{m}} \\
(\mathrm{M})\end{array}$ & $\begin{array}{l}K_{\text {cat }} \\
\left(\mathrm{s}^{-1}\right)\end{array}$ & $\begin{array}{l}K_{\mathrm{cat}} / K_{\mathrm{m}} \\
\left(\mathrm{s}^{-1} \mathrm{M}^{-1}\right)\end{array}$ \\
\hline Farnesyl triphosphate & $36.7 \pm 1.5$ & $\begin{array}{l}0.15 \pm 0.03 \\
\mathrm{x} 10^{-3}\end{array}$ & $34.9 \times 10^{-3}$ & 232 \\
\hline Isopentenyl triphosphate & $76.7 \pm 3.0$ & $\begin{array}{l}0.63 \pm 0.20 \\
\mathrm{x} 10^{-3}\end{array}$ & $72.9 \times 10^{-3}$ & 116 \\
\hline Geranyl triphosphate & $33.6 \pm 5.7$ & $\begin{array}{l}0.31 \pm 0.07 \\
\times 10^{-3}\end{array}$ & $31.9 \times 10^{-3}$ & 103 \\
\hline Farnesyl diphosphate & $2.9 \pm 0.4$ & $\begin{array}{l}0.05 \pm 0.01 \\
\times 10^{-3}\end{array}$ & $2.8 \times 10^{-3}$ & 56 \\
\hline Isopentenyl diphosphate & $33.3 \pm 10.6$ & $\begin{array}{l}2.3 \pm 0.93 \\
\times 10^{-3}\end{array}$ & $31.6 \times 10^{-3}$ & 13.8 \\
\hline Dimethylallyl diphosphate & $51.8 \pm 1.5$ & $\begin{array}{l}4.0 \pm 0.2 \\
\times 10^{-3}\end{array}$ & $49.2 \times 10^{-3}$ & 12.3 \\
\hline Geranyl diphosphate & $0.85 \pm 0.03$ & $\begin{array}{l}0.21 \pm 0.02 \\
\times 10^{-3}\end{array}$ & $0.8 \times 10^{-3}$ & 3.8 \\
\hline
\end{tabular}

